\title{
Erythroid progenitors (BFU-e and CFU-e) in acute leukaemia
}

\author{
A. URABE 1 , M. J. MURPHY, JR, M. HAGHBIN, AND T. S. GEE \\ From Memorial Sloan-Kettering Cancer Center, 1275 York Avenue, New York, NY 10021, USA
}

SUMMARY Bone marrow erythroid progenitor cells were examined from 50 cases of acute leukaemia and from 20 normal subjects using an in vitro semisolid culture method. Numbers of both primitive erythroid progenitor cells (BFU-e) and later-stage erythroid progenitor cells (CFU-e) were remarkably depressed in patients with acute leukaemia in active phase. However, both BFU-e and CFU-e recovered to within normal range when the patients achieved remission. Peripheral blood BFU-e of children with acute lymphocytic leukaemia in remission were also examined and found to have values not significantly different from those of control subjects. There was no distinct correlation between the numbers of erythroid bursts or colonies and the duration of remission in patients with acute leukaemia in remission. The reduction of BFU-e and CFU-e in active acute leukaemia suggests the involvement of erythropoietic progenitors in the pathophysiology of this type of leukaemia.

In vitro culture of bone marrow cells has recently been applied to clinical studies, allowing the detection of early changes of haematopoietic progenitor cells in patients with various haematological diseases (Metcalf, 1977). Many of these studies have exploited the technical advances made in the field of granulopoiesis (Moore, 1974). For example, an examination of CFU-c (that is, the granulocytemacrophage progenitor) has led to the discovery of the early changes in the in vitro colony-forming pattern which sometimes predictably precedes clinical development of blastic crisis in patients with chronic myelogenous leukaemia (Moore, 1975). Complementary techniques have now been developed which in turn have fostered studies of the red cell series. Erythropoietin-dependent, late-stage progenitor cells, that is, colony-forming uniterythroid (CFU-e) (Stephenson et al., 1971), and more primitive early-stage progenitor cells, that is, burst-forming unit-erythroid (BFU-e), can now be quantitated using semisolid culture methods(Axelrad et al., 1974). A search of the literature, however, has revealed few references in which erythroid progenitor cells from patients with acute leukaemia were exam-

${ }^{1}$ Present address: Third Department of Internal Medicine, Faculty of Medicine, University of Tokyo, Hongo, Tokyo 113, Japan.

Received for publication 2 January 1979 ined (Mizoguchi et al., 1977; Tebbi and Gross, 1977). In this communication we describe the growth and differentiating characteristics of erythroid progenitor cells (BFU-e and CFU-e) in patients with acute leukaemia and in normal subjects.

\section{Patients and methods}

From April to November 1977, adult patients with acute non-lymphocytic leukaemia (including acute myeloblastic leukaemia, acute monocytic leukaemia, acute promyelocytic leukaemia, acute myelomonocytic leukaemia, and acute forms of erythroleukaemia) were studied. Children (under 15 years at diagnosis) with acute lymphocytic leukaemia were also enrolled in this study. To ensure controlled studies of adult patients, healthy volunteers were recruited. For controlled studies of paediatric patients with acute lymphocytic leukaemia, children with non-haematological diseases but whose marrow had been examined during routine diagnostic procedures were chosen. All the children with acute lymphocytic leukaemia in remission were off chemotherapy at the time of examination.

REGULAR BFU-e AND CFU-e ASSAY

Methylcellulose culture methodology, which was originally described by Iscove et al. (1974), was used with slight modifications (Murphy and Sullivan, 
1978). Bone marrow was aspirated from the posterior iliac crest. Diluted heparinised bone marrow cells were applied to Ficoll-Isopaque for cell separation, and $2 \times 10^{5}$ nucleated bone marrow cells were suspended in $\alpha$ medium (Flow Laboratories, Rockville, Maryland, USA) containing $0 \cdot 8 \%$ methylcellulose (The Dow Chemical Co, Midland, Michigan, USA), $30 \%$ fetal bovine serum (Flow Labs No 240 ), $1 \%$ bovine serum albumin (Calbiochem, San Diego, California, USA), and 1 unit of human urinary erythropoietin (38 international units $/ \mathrm{mg}$ ) in a final volume of $1 \mathrm{ml}$ in $35 \times 10 \mathrm{~mm}$ Petri dishes (Lux Scientific Corporation, Newbury Park, California, USA). The erythropoietin was concentrated by $\mathrm{Dr}$ P. P. Dukes, of Childrens Hospital of Los Angeles, and distributed by the National Heart, Lung, and Blood Institute under grant HL-10880. These cell suspensions were then incubated at $37^{\circ} \mathrm{C}$ in $5 \% \mathrm{CO}_{2}$ and $95 \%$ air with saturated humidity. After seven days' incubation, the numbers of erythrocytic colonies were counted, and on day 14 erythropoietic bursts were enumerated using an inverted microscope without staining. Reddish or red colonies, which had more than eight cells on day 7 , were identified as erythroid colonies derived from CFU-e, and reddish or red bursts with macroscopic dimensions on day 14 were identified as erythropoietic bursts derived from BFU-e. The morphology of the cells was confirmed by cytocentrifugation and staining with Wright-Giemsa.

\section{MINIATURISED ASSAY FOR ERYTHROID \\ PROGENITORS}

A small amount of peripheral blood was also taken from the paediatric patients, and the nucleated cells were cultured using the technology described previously, except that flat-bottomed microtitre plates (Cooke Laboratory Products, Alexandria, Virginia, USA) were used as a culture vessel (Urabe and Murphy, 1978). In the presence of 1 unit of erythropoietin per $\mathrm{ml} 1-2 \times 10^{5}$ nucleated peripheral blood cells were plated in a final volume of $0.1 \mathrm{ml}$ per microtitre well. Six microtitre wells were used for each BFU-e determination.

For statistical analysis, Student's $t$ test was used.

\section{Results}

The number of colonies and bursts showed a dosedependency corresponding to the concentrations of cells as well as to erythropoietin. The duration of this study was intentionally limited, using the same reagents in all the experiments. Thus the same plating efficiency for normal bone marrow was observed throughout.

The numbers of CFU-e and BFU-e from adult and paediatric patients with acute leukaemia in remission were not significantly different from control values ( $t$ test, $\mathrm{P}>0.05$ ), but the numbers of CFU-e and BFU-e from patients in active phase were significantly lower than those of control subjects $(t$ test, $\mathrm{P}<0.05)$. Table 1 summarises these data. There were no significant correlations between the numbers of CFU-e or BFU-e and the duration of remission or time off chemotherapy. Detailed data of the patients in remission are given in Tables 2 and 3. Of 17 cases of adult acute non-lymphocytic leukaemia in remission, only two patients relapsed, both almost one year after the bone marrow culture. One patient died in complete remission due to hepatitis. The remaining 14 patients are alive and in remission (1 July 1978). In 22 cases of paediatric acute lymphocytic leukaemia in remission, only one patient relapsed, three months after the bone marrow culture. The remainder are in remission without chemotherapy (1 July 1978).

Table 1 Summary of erythroid progenitors of bone marrow in patients and controls

\begin{tabular}{|c|c|c|c|}
\hline Subjects & No. & $C F U-e^{*}$ & $B F U-e^{*}$ \\
\hline \multicolumn{4}{|l|}{ Adult } \\
\hline Control & 16 & $70 \cdot 5 \pm 10 \cdot 2$ & $22 \cdot 1 \pm 7 \cdot 0$ \\
\hline $\begin{array}{l}\text { Acute non-lymphocytic } \\
\text { leukaemia in remission }\end{array}$ & 17 & $75 \cdot 1 \pm 13 \cdot 2$ & $37 \cdot 7 \pm 9 \cdot 2$ \\
\hline $\begin{array}{l}\text { Acute non-lymphocytic } \\
\text { eukaemia, active phase } \\
\text { Paediatric }\end{array}$ & 7 & $13.8 \pm 10 \cdot 1 \dagger$ & $0.7 \pm 0.7 \dagger$ \\
\hline Control & 4 & $80 \cdot 1 \pm 33 \cdot 8$ & $32 \cdot 1 \pm 8.7$ \\
\hline $\begin{array}{l}\text { Acute lymphocytic } \\
\text { leukaemia in remission }\end{array}$ & 22 & $56 \cdot 0 \pm 8 \cdot 2$ & $29 \cdot 3 \pm 5 \cdot 3$ \\
\hline $\begin{array}{l}\text { Acute lymphocytic } \\
\text { leukaemia, active phase }\end{array}$ & 4 & $4.0 \pm 3.4 \dagger$ & $0+$ \\
\hline
\end{tabular}

* Per $10^{5}$ nucleated bone marrow cells; mean $\pm \mathrm{SE}$

†Significantly different from the value of controls ( $t$ test, $P<0.05$ ).

Microtitre plates used to grow erythropoietic bursts from peripheral blood showed reliability in terms of plating efficiency. This result was a function of different concentrations of cells as well as different concentrations of erythropoietin. Experiments in which identical cell suspensions were cultured using both regular $35 \mathrm{~mm}$ Petri dishes and microtitre plates simultaneously confirmed this observation (data not shown).

Peripheral blood BFU-e were assayed in 11 children with acute lymphocytic leukaemia in remission and in three paediatric controls. Mean number $( \pm$ SE) of erythropoietic bursts of peripheral blood from children with acute lymphocytic leukaemia in remission was $3.5 \pm 1.4$ per $10^{5}$ nucleated cells, which was not significantly different from control values $(3.1 \pm 0.5, \mathrm{SE}, t$ test, $\mathrm{P}>0.05)$.

Peripheral blood and bone marrow of children 
Table 2 Adult acute non-lymphocytic leukaemia in remission

\begin{tabular}{|c|c|c|c|c|c|c|c|}
\hline \multirow[t]{2}{*}{ Case } & \multirow[t]{2}{*}{ Age (yr) and sex } & \multirow[t]{2}{*}{$H b(g / d l)$} & \multirow[t]{2}{*}{$W B C \times 10^{2} / \mathrm{mm}^{3}$} & \multirow[t]{2}{*}{ Platelet $\times 10^{2} / \mathrm{mm}^{3}$} & \multirow{2}{*}{$\begin{array}{l}\text { Duration of remission } \\
\text { (months) }\end{array}$} & $C F U-e$ & $B F U-e$ \\
\hline & & & & & & \multicolumn{2}{|c|}{$\begin{array}{l}10^{s} \text { nucleated } \\
\text { marrow cells }\end{array}$} \\
\hline $\begin{array}{c}1 \\
2 \\
3 \\
4 \\
5 \\
6 \\
7 \\
8{ }^{*} \\
9 \\
10 \\
11 \\
12 \\
13 \dagger \\
14 \\
15 \\
16 \dagger \\
17\end{array}$ & $\begin{array}{ll}53 & \mathrm{~F} \\
29 & \mathrm{~F} \\
40 & \mathrm{~F} \\
37 & \mathrm{M} \\
37 & \mathrm{M} \\
46 & \mathrm{M} \\
72 & \mathrm{~F} \\
40 & \mathrm{M} \\
32 & \mathrm{M} \\
32 & \mathrm{M} \\
31 & \mathrm{~F} \\
27 & \mathrm{M} \\
66 & \mathrm{~F} \\
63 & \mathrm{M} \\
28 & \mathrm{M} \\
66 & \mathrm{~F} \\
51 & \mathrm{M}\end{array}$ & $\begin{array}{r}12 \cdot 0 \\
13 \cdot 1 \\
14 \cdot 1 \\
16.6 \\
16 \cdot 4 \\
14 \cdot 3 \\
13 \cdot 5 \\
10 \cdot 6 \\
13 \cdot 2 \\
14 \cdot 8 \\
10 \cdot 0 \\
10 \cdot 6 \\
10.6 \\
14.9 \\
9.2 \\
9.7 \\
15 \cdot 5\end{array}$ & $\begin{array}{r}5 \cdot 7 \\
7 \cdot 7 \\
11.5 \\
8.3 \\
8 \cdot 1 \\
3.8 \\
4 \cdot 3 \\
6.3 \\
4 \cdot 5 \\
7 \cdot 2 \\
9.3 \\
7.7 \\
11.6 \\
8.2 \\
8.5 \\
8.9 \\
6.0\end{array}$ & $\begin{array}{l}146 \\
221 \\
352 \\
218 \\
200 \\
145 \\
115 \\
154 \\
176 \\
306 \\
386 \\
140 \\
300 \\
159 \\
145 \\
147 \\
195\end{array}$ & $\begin{array}{l}\mathbf{N C} \\
\mathbf{N C} \\
66 \\
53 \\
50 \\
13 \\
19 \\
21 \\
4 \\
6 \\
1 \\
1 \\
2 \\
23 \\
2 \\
3 \\
23\end{array}$ & $\begin{array}{r}15 \\
250 \\
59 \\
123 \\
55 \\
4 \\
71 \\
30 \\
85 \\
39 \\
56 \\
77 \\
71 \\
92 \\
72 \\
75 \\
102\end{array}$ & $\begin{array}{r}21 \\
140 \\
24 \\
7 \\
53 \\
0 \\
24 \\
3 \\
104 \\
43 \\
57 \\
21 \\
3 \\
66 \\
10 \\
24 \\
41\end{array}$ \\
\hline
\end{tabular}

NC $=$ not clear.

-Died from hepatitis in complete remission.

+Relapsed later.

Table 3 Paediatric acute lymphocytic leukaemia in remission

\begin{tabular}{|c|c|c|c|c|c|c|c|c|}
\hline \multirow[t]{2}{*}{ Case } & \multirow{2}{*}{$\begin{array}{l}\text { Age (yr) } \\
\text { and sex }\end{array}$} & \multirow[t]{2}{*}{$H b(g / d l)$} & \multirow[t]{2}{*}{$W B C \times 10^{3} / \mathrm{mm}^{3}$} & \multirow[t]{2}{*}{ Platelet $\times 10^{3} / \mathrm{mm}^{2}$} & \multirow{2}{*}{$\begin{array}{l}\text { Duration off } \\
\text { chemotherapy } \\
\text { (months) }\end{array}$} & CFU-e & BFU-e & \multirow{2}{*}{$\begin{array}{l}\text { BFU-e*/10' } \\
\text { mucleated } \\
\text { peripheral } \\
\text { blood cells }\end{array}$} \\
\hline & & & & & & \multicolumn{2}{|c|}{$\begin{array}{l}10^{s} \text { nucleated } \\
\text { marrow cells }\end{array}$} & \\
\hline 1 & $9 \mathrm{~F}$ & 13.0 & $6 \cdot 5$ & 270 & 18 & 29 & 9 & ND \\
\hline 2 & $6 \mathrm{~F}$ & $11 \cdot 6$ & $6 \cdot 8$ & 300 & 25 & 105 & ND & ND \\
\hline 3 & $7 \mathrm{~F}$ & $11 \cdot 5$ & $5 \cdot 1$ & 260 & 50 & 17 & ND & ND \\
\hline 4 & $10 \mathrm{M}$ & $13 \cdot 1$ & $5 \cdot 1$ & 390 & 2 & 51 & 29 & ND \\
\hline 5 & $7 \mathrm{M}$ & $12 \cdot 3$ & $8 \cdot 2$ & 550 & 18 & 68 & 9 & ND \\
\hline 6 & $17 \mathrm{M}$ & $17 \cdot 2$ & 10.9 & 360 & 29 & 23 & 8 & ND \\
\hline $7 \dagger$ & $8 \mathrm{M}$ & $12 \cdot 4$ & 6.7 & 480 & 5 & 28 & 34 & $4.5 \pm 0.5$ \\
\hline 8 & $11 \mathrm{M}$ & 12.9 & $8 \cdot 6$ & 400 & 53 & 36 & 38 & ND \\
\hline 9 & $8 \mathrm{M}$ & $12 \cdot 3$ & 6.8 & 430 & 7 & 75 & 55 & $\mathbf{N D}$ \\
\hline 10 & $9 \mathrm{M}$ & 13.0 & 6.6 & 390 & 17 & 40 & 19 & ND \\
\hline 11 & $12 \mathrm{M}$ & $12 \cdot 2$ & $6 \cdot 3$ & 380 & 11 & 36 & 32 & $4.1 \pm 0.3$ \\
\hline 12 & $14 \mathrm{M}$ & $14 \cdot 5$ & $6 \cdot 7$ & 270 & 44 & 64 & 8 & $0.5 \pm 0.2$ \\
\hline 13 & $12 \mathrm{M}$ & $14 \cdot 9$ & $8 \cdot 1$ & 350 & 9 & 30 & 50 & $2.4 \pm 0.2$ \\
\hline 14 & $8 \mathrm{~F}$ & 12.9 & $7 \cdot 0$ & 280 & 22 & 34 & 6 & ND \\
\hline 15 & $8 \mathrm{M}$ & $13 \cdot 5$ & 5.8 & 380 & 10 & 143 & 102 & $16.2 \pm 1.6$ \\
\hline 16 & $7 \mathrm{M}$ & $13 \cdot 3$ & 8.0 & 360 & 33 & 47 & 31 & $4.1 \pm 0.3$ \\
\hline 17 & $8 \mathrm{~F}$ & 12.9 & $6 \cdot 1$ & 450 & 23 & 5 & 0 & ND \\
\hline 18 & $8 \mathrm{~F}$ & $11 \cdot 7$ & $9 \cdot 7$ & 440 & 21 & 86 & 43 & $0.3 \pm 0.1$ \\
\hline 19 & $11 \mathrm{~F}$ & 11.9 & $8 \cdot 2$ & 320 & 42 & 57 & 17 & $2.3 \pm 0.2$ \\
\hline 20 & $11 \mathrm{M}$ & 13.0 & $5 \cdot 4$ & 225 & 6 & 137 & 45 & $1.4 \pm 0.1$ \\
\hline 21 & $12 \mathrm{M}$ & $11 \cdot 8$ & $6 \cdot 2$ & 460 & 27 & 105 & 41 & $2.2 \pm 0.3$ \\
\hline 22 & $11 \mathrm{M}$ & $12 \cdot 0$ & $6 \cdot 6$ & 340 & 11 & 15 & 10 & $0.6 \pm 0.2$ \\
\hline
\end{tabular}

-Mean \pm standard error of BFU-e from six replicate microtitre wells.

ND = not done.

†Relapsed later.

with acute lymphocytic leukaemia in remission were examined at the same time. The observed correlation between the numbers of bursts from bone marrow and peripheral blood was $\mathrm{r}=0.83, \mathrm{P}<0.001$.

\section{Discussion}

Granulocyte-macrophage progenitors (CFU-c) have been studied extensively in patients with leukaemia (Moore, 1974). Moore et al. (1974) attempted to reclassify acute leukaemia according to the culture findings of CFU-c, because the growth pattern of CFU-c correlated better with the patient's prognosis than conventional laboratory findings. It is of more interest that in some cases of chronic myelogenous leukaemia, blastic crisis can be predicted using the 
agar culture results of CFU-c before the clinical signs of acute exacerbation appear (Moore, 1975).

In our results in acute leukaemia reported here, primitive erythroid progenitors (BFU-e) showed changes comparable to the pattern of late-stage erythroid progenitors (CFU-e) in that both committed stem cells decreased during the active phase of disease and both recovered to within a normal range in remission. Tebbi and Gross (1977) reported that CFU-e in children with acute lymphocytic leukaemia in remission showed a significantly lower value than that of controls. However, each of their patients in remission was receiving chemotherapy at the time of examination (Dr Tebbi, personal communication). All our paediatric patients with acute lymphocytic leukaemia in remission were off chemotherapy, and the numbers of BFU-e and CFU-e for the majority of them revealed values within the normal range.

It is well accepted that BFU-e are closely related to the pluripotent stem cell (Iscove, 1977). The fact that, in patients with acute leukaemia in active phase, the numbers of not only CFU-e but also BFU-e decreased concomitant with a reduction in the number of CFU-c of normal origin (Spitzer et al., 1978) suggests that haematopoietic stem cells are impaired in acute leukaemia, or at least erythropoietic progenitors are seriously suppressed by the leukaemic clone. Since most of the patients with acute leukaemia in remission reported here are still in remission, we are at present unable to comment on the possibility of prognostic prediction using erythroid assays. This information is currently being accumulated.

Peripheral blood BFU-e obtained using microtitre plates correlated with bone marrow BFU-e obtained by the regular method. This supports the usefulness of this miniaturised method for monitoring erythroid progenitors in some clinical cases where it is difficult to obtain an adequate number of cells for routine culture conditions (Urabe and Murphy, 1978).

This work was supported by grants AM-19741 from the USPHS and the Bob Hipple Fund. We are especially indebted to Dr Bayard D. Clarkson for clinical cooperation. The support and criticism of Dr M. A. S. Moore is also acknowledged. We are grateful to Ms M. E. Sullivan for technical help, and to Ms J. Zisson for assistance in the preparation of this manuscript.

\section{References}

Axelrad, A. A., McLeod, D. L., Shreeve, M. M., and Heath, D. S. (1974). Properties of cells that produce erythrocytic colonies in vitro. In Hemopoiesis in Culture, edited by W. A. Robinson, pp. 226-234. US Government Printing Office, Washington, D.C.

Iscove, N. N. (1977). The role of erythropoietin in regulation of population size and cell cycling of early and late erythroid precursors in mouse bone marrow. Cell and Tissue Kinetics, 10, 323-334.

Iscove, N. N. Sieber, F., and Winterhalter, K. H. (1974). Erythroid colony formation in cultures of mouse and human bone marrow: analysis of the requirement for erythropoietin by gel filtration and affinity chromatography on agarose-concanavalin A. Journal of Cellular Physiology, 83, 309-320.

Metcalf, D. (1977). In-vitro cloning techniques for hemopoietic cells: clinical applications. Annals of Internal Medicine, 87, 483-488.

Mizoguchi, H., Miura, Y., Chiyoda, S., and Takaku, F. (1977). CFU-C and CFU-E in acute leukemia. Topics in Hematology (International Congress Series, 415), edited by S. Seno, F. Takaku, and S. Irino, pp. 483485. Excerpta Medica, Amsterdam.

Moore, M. A. S. (1974). In vitro studies in the myeloid leukaemias. In Advances in Acute Leukaemia, edited by F. J. Cleton, D. Crowther, and J. S. Malpas, pp. 161-227. North-Holland Publishing, Amsterdam.

Moore, M. A. S. (1975). Agar culture studies in CML and blastic transformation. Series Haematologica, 8 (4), 1127.

Moore, M. A. S., Spitzer, G., Williams, N., Metcalf, D., and Buckley, J. (1974). Agar culture studies in 127 cases of untreated acute leukemia: the prognostic value of reclassification of leukemia according to in vitro growth characteristics. Blood, 44, 1-18.

Murphy, M. J., Jr., and Sullivan, M. E. (1978). Culture of erythroid stem cells from murine and human marrow and blood. In In Vitro Aspects of Erythropoiesis, edited by M. J. Murphy, Jr., C. Peschle, A. S. Gordon, and E. A. Mirand, pp. 262-265. SpringerVerlag, New York.

Spitzer, G., Verma, D. S., Dicke, K. A., and McCredie, K. B. (1978). Culture studies in vitro in human leukemia. Seminars in Hematology, 15, 352-378.

Stephenson, J. R., Axelrad, A. A., McLeod, D. L., and Shreeve, M. M. (1971). Induction of colonies of hemoglobin-synthesizing cells by erythropoietin in vitro. Proceedings of the National Academy of Sciences, 68, $1542-1546$.

Tebbi, K., and Gross, S. (1977). Erythropoietic colony forming units in children with acute lymphoblastic leukemia (Abstract). Proceedings of the American Association of Cancer Research, 18, 246.

Urabe, A., and Murphy, M. J., Jr. (1978) Miniaturization of methylcellulose erythroid colony assay. In In Vitro Aspects of Erythropoiesis, edited by M. J. Murphy, Jr., C. Peschle, A. S. Gordon, and E. A. Mirand, pp. 28-30. Springer-Verlag, New York.

Requests for reprints to: Dr Akio Urabe, Third Department of Internal Medicine, Faculty of Medicine, University of Tokyo, Hongo, Tokyo 113, Japan. 